\title{
NAPHTHALENE AND AQUEOUS ACETONE
}

\author{
BY HAMILTON P. CADY
}

At the suggestion of Prof. Bancroft I have made a partial investigation of the system naphthalene, acetone, and water. The acetone used was purified by drying with calcium chlorid and fractionating. The naphthalene was recrystallized from alcohol. The mixtures of acetone and water were made up so as to contain approximately $10,20,30,40,50,60$ and $7^{\circ}$ percent of acetone by weight. Naphthalene in excess was added to each solution and the temperatures determined at which a second liquid phase first appeared. In order to determine the composition of the liquid phase at this point, the following method was adopted: A weighed quantity of naphthalene was added to a known weight of the mixed liquids, the amount being just sufficient to canse the formation of two liquid phases. The consolute temperature of the system was then determined, and the experiment repeated several times with different annonnts of naphthalene. If the results are plotted using the weights of naphthalene in a constant quantity of the mixed liquids as abscissas and the temperatures as ordinates, we shall get a series of curves. The composition of the liquid phase at the moment when the system passes from solid, solution and vapor to solid, two solutions and rapor is given by the point at which the prolongation of the curve for that particular mixture of acetone and water. cuts the ordinate for the temperature at which the change takes place. This method requires 110 analyses and is of advantage in this case where ordinary quantitative analysis wonld be very difficult. The method involves but one assumption, that the field for two liquicl phases and vapor lies within the boundary curve. Preliminary experiments showed that this was the case for no unsaturated solution of maphthalene, acetone and water 
could be found which formed two liquid layers upon heating.

Considerable difficulty was experienced in determining the consolute temperatures. Orring to the volatility of the acetone the solutions conld not be heated in corked test-tubes. Pressure flasks were tried but proved unsatisfactory for, sooner or later, they would leak and perhaps spoil a series of determinations. It was finally found necessary to seal each mixture of aqueon. acetone and naphthalene in a glass tube. This was, of course, a laborious process since separate tubes had to be made for each determination.

The experinental data are given in Tables I-III. In Table I are given the percentage acetone in the aqueons acetone, the anounts of naphthalene added to one hundred grams of the aqueous acetone and the corresponding consolute temperatures for the resulting solutions. In Table II are the temperatures at which different solutions begin to separate into two lavers in presence of solid naphthalene and the compositions of these solutions. In Table III are the data for portions of varions isotherms, obtained by interpolation from the figures in Table I.

Table I

\begin{tabular}{|c|c|c|c|c|c|c|c|}
\hline \multicolumn{2}{|c|}{$\begin{array}{c}\text { Percentage } \\
\text { acetone. }\end{array}$} & & \multicolumn{4}{|c|}{$\begin{array}{l}\text { Naphthalene in Ioo grams solvent. } \\
\text { Consolute temperatures. }\end{array}$} & \\
\hline 10.01 & O. 109 & & $7^{\circ}$ & 0.125 & $85^{\circ}$ & 0.127 & $90^{\circ}$ \\
\hline 19.94 & 0.368 & & $8_{3}$ & 0.433 & 92 & 0.447 & 94 \\
\hline 30.04 & 0.585 & & $6 \mathrm{I} . \mathrm{I}$ & 0.674 & 68 & $0.80 \mathrm{I}$ & 74 \\
\hline+1.20 & 1.038 & & $4 I$ & I. 587 & $67 \cdot 4$ & $3 \cdot 7+5$ & 100.5 \\
\hline .99 & 2.790 & & 39.2 & 4.019 & 58 & +.960 & $7+$ \\
\hline 0.3 & 7.082 & & $39 \cdot 3$ & 7.383 & 43.2 & 7.901 & 49.8 \\
\hline 70.12 & 16.067 & & 28.2 & I 7.978 & 49 & $\ldots$ & $\ldots$ \\
\hline
\end{tabular}

Table II

\begin{tabular}{c|c|c|c} 
Acetone & Water & Naphthalene & Temperature \\
\hdashline 10.00 & 89.92 & 0.08 & 65.5 \\
1991 & 80.00 & 0.09 & 55.3 \\
29.92 & 69.67 & 0.41 & 45.0 \\
40.81 & 58.22 & 0.97 & 38.0 \\
48.67 & 48.68 & 2.65 & 32.2 \\
57.43 & 36.64 & 5.93 & 28.5 \\
60.43 & 25.75 & I3.82 & 28.2
\end{tabular}


Table III

\begin{tabular}{|c|c|c|c|c|c|c|}
\hline $\begin{array}{l}\left(\mathrm{CH}_{3}\right)_{2} \mathrm{CO} \\
\mathrm{H}_{2} \mathrm{O} \\
\mathrm{C}_{10} \mathrm{H}_{5}\end{array}$ & $70^{\circ}$ & $\begin{array}{r}\text { IO.0I } \\
89.90 \\
0.09\end{array}$ & $\begin{array}{l}19.88 \\
79.89 \\
0.23\end{array}$ & $\begin{array}{r}29.84 \\
69.46 \\
0.70\end{array}$ & $\begin{array}{r}40.53 \\
57.82 \\
1.65\end{array}$ & $\begin{array}{r}47 \cdot 73 \\
47 \cdot 76 \\
4 \cdot 51 \\
\end{array}$ \\
\hline $\begin{array}{l}\left(\mathrm{CH}_{3}\right)_{2} \mathrm{CO} \\
\mathrm{H}_{2} \mathrm{O} \\
\mathrm{C}_{10} \mathrm{H}_{8}\end{array}$ & $60^{\circ}$ & $\begin{array}{r}19.93 \\
79.95 \\
0.12\end{array}$ & $\begin{array}{r}29.87 \\
69.56 \\
0.57\end{array}$ & $\begin{array}{r}40.62 \\
57.96 \\
1.42\end{array}$ & $\begin{array}{r}47.97 \\
48.02 \\
4.01\end{array}$ & $\begin{array}{r}56.04 \\
35.75 \\
8.2 I \\
\end{array}$ \\
\hline $\begin{array}{l}\left(\mathrm{CH}_{3}\right)_{2} \mathrm{CO} \\
\mathrm{H}_{2} \mathrm{O} \\
\mathrm{C}_{10} \mathrm{H}_{5}\end{array}$ & $50^{\circ}$ & $\begin{array}{r}29.91 \\
69.63 \\
0.46\end{array}$ & $\begin{array}{r}40.72 \\
58.08 \\
1.20\end{array}$ & $\begin{array}{r}48.23 \\
48.28 \\
3.49\end{array}$ & $\begin{array}{r}56.55 \\
36.08 \\
7.37 \\
\end{array}$ & \\
\hline $\begin{array}{l}\left(\mathrm{CH}_{3}\right)_{2} \mathrm{CO} \\
\mathrm{H}_{2} \mathrm{O} \\
\mathrm{C}_{10} \mathrm{H}_{i}\end{array}$ & $40^{\circ}$ & $\begin{array}{r}40.79 \\
58.20 \\
1.01\end{array}$ & $\begin{array}{r}48.43 \\
48.49 \\
3.18\end{array}$ & $\begin{array}{r}56.99 \\
36.34 \\
6.67\end{array}$ & $\begin{array}{l}5965 \\
25.3 \mathrm{I} \\
15.04\end{array}$ & \\
\hline $\begin{array}{l}\left(\mathrm{CH}_{3}\right)_{2} \mathrm{CO} \\
\mathrm{H}_{2} \mathrm{O} \\
\mathrm{C}_{10} \mathrm{H}_{B}\end{array}$ & $30^{\circ}$ & $\begin{array}{r}57 \cdot 36 \\
36.58 \\
6.06\end{array}$ & $\begin{array}{l}60.35 \\
25.70 \\
13.95\end{array}$ & & & \\
\hline
\end{tabular}

The addition of a very small quantity of naphthalene raises the consolute temperature so much that, if isotherms $10^{\circ}$ apart be plotted on triangular coordinate paper, the curves lie so close together as to be indistinguishable for the greater part of their course. For this reason it was not deemed advisable to represent the results graphically. In the solid diagram with the temperature measured along the vertical axis, the surface for two solutions and vapor would rise almost perpendicularly from the boundary curve.

Cornell University 